\title{
The New Paradigm for Emerging Economies
}

Sheikh Mohammed Irfan ${ }^{1}$ and Skyler Blacker ${ }^{1}$

${ }^{1}$ Affiliation not available

July 19, 2021

\section{Hosted file}

New Paradigm for Emerging Economies.pdf available at https://authorea.com/users/227729/ articles/530748-the-new-paradigm-for-emerging-economies 